\title{
HOW TO USE THIS REPORT
}

Each of the reports on the constitutions, statutes, and rules of the fifty states and the District of Columbia hereafter set forth contains five sections.

The first-Mandatory Retirement Provisions Applicable Generallydeals with involuntary retirement for age, involuntary retirement for disability $;^{1}$ the procedural provisions applicable to the latter, and notation of decisions of the jurisdiction's courts relating to the constitutionality of such provisions or procedures under it. To be noted, however, is that Gregory v. Ashcroft, 501 U.S. 452, upholding the constitutionality of Missouri's mandatory retirement for age, is not referenced except in the Missouri report, but that its reasoning supports the constitutionality of mandatory retirement for age in other jurisdictions imposing such a requirement at least until such time as medical evidence with respect to mental ability of the elderly makes a legislative determination with respect to a particular age unreasonable.

The second section-Retirement Provisions re Particular Courts-as its title indicates, reports on the rules governing retirement from those particular courts that differ from the generally applicable rules. Only a few states differentiate between courts as to retirement.

The third section-Optional Provisions for Retirement-reports on voluntary retirement for age and/or service and voluntary retirement for disability and the procedures related thereto. It does not discuss the amount of either form of retirement benefits, except to note those provisions that equate retirement for disability with voluntary retirement for age and/or service. It also does not as a general matter discuss insurance benefits, survivor benefits, death benefits, or deferred compensation plans, although some reports contain reference to one or more of such provisions.

The section does, however, report provisions authorizing cost of living increase in such benefits, and those that protect such benefits from various

\footnotetext{
${ }^{1}$ In some states involuntary retirement for disability is dealt with in the same statute concerned with impeachment. However, impeachment is not discussed in the reports.
} 
forms of legal process and prohibit assignment, except for amounts due from the retiree to the retirement system or for child or spousal support pursuant to court judgment or decree.

The fourth section-Service After Retirement-deals with the extent to which the state permits retired judges to function in a judicial capacity: whether as senior judge, special judge, surrogate judge, temporary judge, judicial hearing officer, or other titles, how long after retirement the retiree may continue in that capacity, and the extent to which continuation is dependent upon periodic mental and/or physical examination, and whether a retiree so serving is required to attend continuing education courses. It also reports on provisions that permit a retiree to serve as an arbitrator or mediator in a court-related or privately sponsored alternative dispute resolution proceeding, or as a member of a commission or other body related to the judiciary.

The fifth section-Pay and Emoluments-concerns how a retiree is compensated for service after retirement, whether he or she is entitled to credit for such service toward receiving maximum retirement benefits if he or she retired at an earlier age or with fewer years of service than required for that purpose, whether only time spent in hearing is compensated or whether time in research and preparation of a decision is also paid for, whether travel and expenses are compensated, and whether such a retiree continues to be included in health or other insurance programs.

With respect to the five paragraphs preceding this one, it should be noted that if a particular state report does not discuss an item referred to in those paragraphs, such as cost of living increase in retirement benefits, exemption of such benefits from tax or legal process, continuing education for retirees serving after retirement, no such provision has been found in the state's constitution, statute, or rules.

Production of this volume was begun in 1995 and completed in mid1998 , but in view of the large number of constitutional and statutory provisions and court rules covered, it has not been possible to bring each such provision up to date of publication of this volume by searching for possible change after the report was put in final form. Therefore, users of this volume interested in a particular provision or rule should review the state's post-1996 legislative materials for possible repeal, revision, or amendment.

A word should be said concerning the research supporting the fifty-one reports contained herein. When the research by students and others was done, the format of the reports had not been developed. When it was 
decided to use the format as a basis for preparing proposed uniform provisions, follow-up research was done for each of the fifty-one jurisdictions to be sure that all relevant provisions were included. That research began with the General Index and covered all relevant index headings, the constitution or statute provisions thus uncovered and the annotations thereto, and legislative materials enacted or adopted thereafter up to the time of preparation of the report for the particular state.

The sections of this volume that follow set forth:

1. a review of the retirement provisions in the fifty-one jurisdictions, titled "Why Judicial Retirement Laws Should Be Changed";

2. a section titled "How Judicial Retirement Laws Should Be Changed," proposing simplification and, to the extent possible, uniformity in those provisions;

3. the fifty-one reports that form the basis for the study and the simplification proposals. 
